\title{
RANCANG BANGUN PENENTUAN POSISI SEPAK BOLA BERODA MENGGUNAKAN METODE ODOMETRY DAN KONTROL PID (PROPORTIONAL INTEGRAL DERIVATIVE)
}

\author{
Aditya Ramadhani ${ }^{1 *}$, M. Taufiqurrohman ${ }^{2}$, Joko Subur ${ }^{3}$ \\ ${ }^{1}$ Universitas Hang Tuah Surabaya, Kota Surabaya, Provinsi Jawa Timur, 60111, Indonesia \\ ${ }^{2}$ Universitas Hang Tuah Surabaya, Kota Surabaya, Provinsi Jawa Timur, 60111, Indonesia \\ ${ }^{3}$ Universitas Hang Tuah Surabaya, Kota Surabaya, Provinsi Jawa Timur, 60111, Indonesia \\ e-mail: " ${ }^{1}$ ramadhani.aditya @ hangtuah.ac.id , ${ }^{2}$ taufiqurrohman@ hangtuah.ac.id, \\ 3joko.subur@hangtuah.ac.id
}

\begin{tabular}{ccc}
\hline Diterima & Direvisi & Disetujui \\
$01-10-2021$ & $10-10-2021$ & $19-10-2021$ \\
\hline
\end{tabular}

\begin{abstract}
In the Indonesian Wheeled Football Robot Contest (KRSBI) robots are expected to play like humans. One of the most important parts of the robot control system is the positioning of the robot. The odometry method is the most commonly used method to determine the robot's position using readings from a rotary encoder. However, the use of a rotary encoder is prone to slipping so that it will result in an error in the odometry feedback system that gets bigger with time. One of the consequences of the slip is a change in the direction of the robot which will affect the next robot's movement. So it is necessary to use a sensor whose fault is not affected by the previous error. A stable system is also needed to improve actuator performance and robot resource effectiveness. To overcome these problems, this research applies the odometry method to map the robot's position in the field, based on rotary encoder readings and gyroscope sensor readings and applies the PID method to control the angle of the robot's facing direction. By applying this combination to the wheeled soccer robot, it can improve the robot's ability to determine position.
\end{abstract}

Keywords: odometry; PID control; positioning robot; wheeled soccer robot

\begin{abstract}
Abstrak: Pada Kontes Robot Sepak Bola Indonesia Beroda (KRSBI) robot diharapkan dapat bermain layaknya manusia. Salah satu bagian terpenting dari sistem kendali robot adalah penentuan posisi robot. metode odometry adalah metode yang paling umum digunakan untuk menentukan posisi robot menggunakan pembacaan dari rotary encoder. Namun penggunaan rotary encoder rawan mengalami slip sehingga akan menghasilkan error pada sistem umpan balik odometry yang semakin besar dengan seiring waktu. Salah satu akibat dari slip adalah perubahan arah hadap robot yang akan memengaruhi pergerakan robot selanjutnya. Sehingga diperlukan penggunaan sensor yang kesalahannya tidak terpengaruh oleh kesalahan sebelumnya. Sistem yang stabil juga diperlukan untuk meningkatkan kinerja aktuator dan efektifitas sumber daya robot. Untuk mengatasi permasalahan tersebut dalam penelitian ini menerapkan metode odometry untuk memetakan posisi robot dilapangan, dengan berdasarkan pembacaan rotary encoder dan pembacaan sensor gyroscope serta menerapkan metode PID untuk mengontrol sudut arah hadap robot. Dengan diterapkannya kombinasi ini pada robot sepak bola beroda dapat meningkatkan kemampuan robot dalam menentukan posisi.
\end{abstract}

Kata kunci: odometry, kontrol PID, penentuan posisi robot, robot sepak bola beroda

\section{PENDAHULUAN}

Perkembangan robot di Indonesia saat ini sangat pesat. sebagai penunjang perkembangan robot di Indonesia Menristekdikti mengadakan Kontes Robot Indonesia (KRI) dengan berbagai macam tema atau divisi. Salah satunya adalah Kontes Robot Sepakbola Beroda (KRSBI Beroda). Dalam kontes tersebut mahasiswa dituntut untuk mengembangkan beberapa kemampuan diantaranya adalah kemampuan pada bidang mekanika, elektronika, pemrograman, articial 
intellegent, image processing, komunikasi digital, strategi, dan kemampuan softskill lainnya (Buku Panduan KRSBI Beroda, 2018).

Pada divisi KRSBI Beroda robot ditanamkan kecerdasan yang dapat meniru sistem kerja manusia saat bermain sepak bola sungguhan, sehingga robot secara otomatis bermain sepak bola sesuai dengan aturan yang telah ditetapkan. Salah satu bagian terpenting dari sistem kendali robot sepak bola beroda adalah pemosisian pada robot (Abseno, 2019)

Pemosisian robot adalah masalah utama dalam pembuatan robot otomatis. Jika robot tidak mengetahui keberadaannya, maka akan sulit untuk menentukan aksi robot selanjutnya (Nasir, 2020). Penelitian yang dilakukan oleh (Rifandi, 2020) menggunakan metode autodocking efektif dan efisien dalam proses menuju lokasi. Pemosisian pada robot meliputi dua aspek penting yaitu penentuan posisi robot dan pengatur kecepatan posisi robot. Untuk mengetahui posisinya, robot mengolah data dari sensornya. Pada robot beroda, penentuan robot yang paling umum digunakan adalah menggunakan rotary encoder untuk mendapatkan kecepatan putaran setiap roda. Nilai kecepatan dan arah diolah untuk mendapatkan posisi robot (Khumaidi et al., 2021).

Robot sepak bola beroda membutuhkan posisi dari dirinya agar rencana geraknya menjadi lebih efisien, sehingga perlu untuk mengatasi kesalahan dalam penentuan posisi robot tersebut. Salah satu tindakan penanggulangan yang dapat dilakukan adalah dengan menggunakan sensor yang kesalahannya tidak terpengaruh oleh kesalahan sebelumnya, misalnya menggunakan sensor gyroscope untuk menentukan arah hadap robot (Rachmawan, 2017).

Untuk mengatasi beberapa permasalahan diatas maka perlu dirancang suatu sistem yang dapat menentukan posisi robot dan kontrol kecepatan robot. Perancangan penentuan posisi robot dilakukan dengan membaca data pergerakan robot dari sistem umpan balik odometry dan sensor gyroscope digunakan untuk mengoreksi arah hadap robot. Sedangkan perancangan kontrol sudut arah hadap robot dilakukan dengan menggunakan metode PID (Proportional Integral Derivative) berdasarkan pembacaan sensor gyroscope. Dengan kombinasi ini diharapkan robot akan bergerak lebih akurat menuju target, dan nilai error yang dihasilkan oleh odometry itu sendiri dapat dikurangi.

\section{METODE PENELITIAN}

Adapun langkah yang dilakukan dalam penilitian ini meliputi perancangan mekanik, kendali pergerakan robot dan perancangan base station. metode odometry digunakan untuk membaca perubahan posisi robot (Basori et al., 2014)dan sudut arah hadap robot dengan menggunakan sistem umpan balik dari kombinasi tiga rotary encoder dan satu buah sensor gyroscope. sensor gyroscope memiliki fitur yang didalam aksi momentum setiap sudut serta orientasi terjaga agar tetap bertahan dan stabil (Firman, 2016).

Dalam bagian ini juga dijelaskan bagaimana persamaan inverse kinematic digunakan untuk menentukan kecepatan masing-masing motor dan Kontrol PID untuk mengolah sinyal error yang berasal dari sistem. Selain itu, alur kerja robot akan dibahas melalui blok sistem robot.

Penelitian ini akan lebih banyak membahas tentang pemetaan lokasi dan arah hadap. Pemetaan lokasi digunakan untuk mendapatkan informasi mengenai lokasi robot. Informasi tersebut dapat digunakan untuk berbagai hal seperti menentukan pergerakan robot, melakukan tendangan ke gawang, melakukan umpan kepada kawan dan lain sebagainya. Uraian proses penelitian ini diuraikan secara berurutan, singkat dan jelas. 


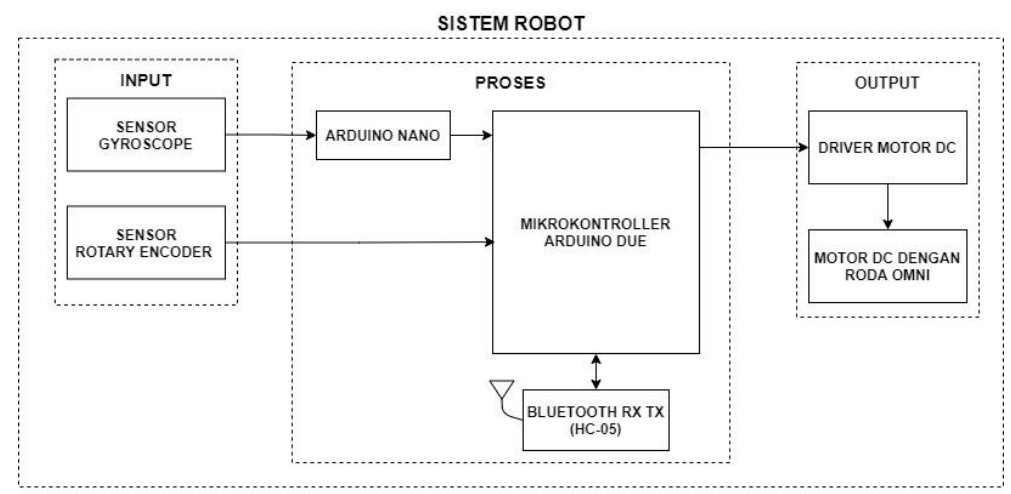

Gambar 1. Diagram blok sistem robot

Terdapat tiga bagian penting dalam sistem robot yaitu masukan, proses dan keluaran(Marisa et al., 2020). Sensor rotary encoder digunakan sebagai sensor untuk pembacaan jumlah putaran roda, sedangkan sensor gyroscope digunakan untuk pembacaan sudut arah hadap robot, proses pembacaan sensor gyroscope menggunakan metode master-slave bertujuan agar proses pembacaan sensor lebih cepat dan akurat dan Bluetooth Rx Tx (HC-05) digunakan sebagai media komunikasi antar robot dengan base station.

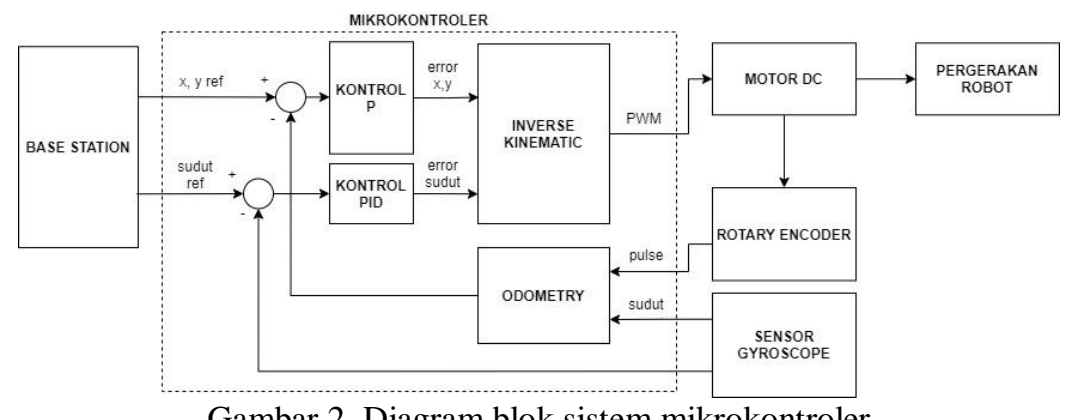

Gambar 2. Diagram blok sistem mikrokontroler

Mikrokontroler menerima data koordinat $\mathrm{x}$, y dan sudut, data yang diterima digunakan sebagai setpoint posisi dan sudut yang harus dituju oleh robot. kontrol P dan kontrol PID digunakan untuk menghasilkan nilai error dari posisi target dan posisi robot saat ini. Selanjutnya nilai error tersebut digunakan sebagai masukkan nilai kecepatan horizontal (vx), kecepatan vertikal (vy) dan kecepatan sudut $(\mathrm{v} \theta)$ pada sistem inverse kinematic. Inverse kinematic digunakan untuk mengatur pergerakan robot dengan membagi kecepatan masing-masing motor berdasarkan nilai masukkan. Pada saat melakukan pergerakan sistem akan membaca posisi robot menggunakan metode odometry berdasarkan pembacaan sensor rotary encoder dan gyroscope.

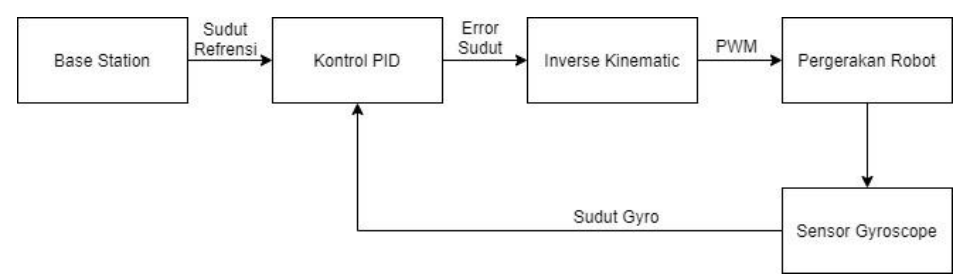

Gambar 3. Diagram blok sistem kontrol PID

Kontrol PID pada penilitian ini digunakan untuk mengoreksi arah hadap robot, sistem akan menerima data sudut target dari base station. Inverse kinematic digunakan untuk mengatur pergerakan robot berdasarkan masukkan yang dihasilkan oleh kontrol PID. 


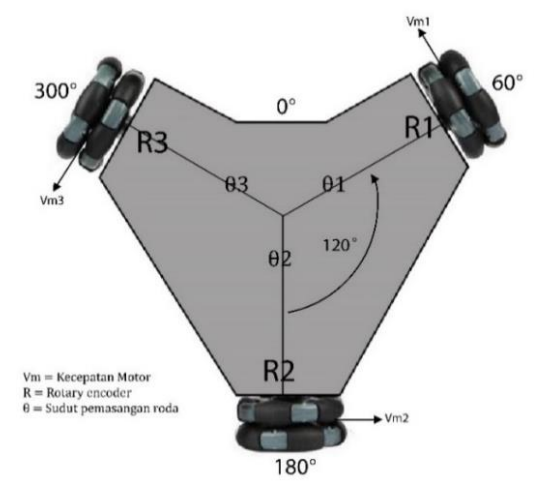

Gambar 4. Desain sistem penggerak

Nilai kecepatan horizontal Vx, kecepatan vertikal Vy dan kecepatan sudut V $\theta$ robot dari sistem kontrol digunakan untuk menetapkan nilai kecepatan pada masing-masing motor. Berdasarkan penempatan motor seperti pada gambar 4 kontrol pergerakan robot omnidirectional beroda 3 didapatkan persamaan seperti berikut:

$$
\left(\begin{array}{l}
V m 1 \\
V m 2 \\
V m 3
\end{array}\right)=\left(\begin{array}{l}
-V x \sin \theta 1+V y \cos \theta 1+V \theta \\
-V x \sin \theta 2+V y \cos \theta 2+V \theta \\
-V x \sin \theta 3+V y \cos \theta 3+V \theta
\end{array}\right)
$$

Dimana:

$\mathrm{Vm} \quad=$ Kecepatan Motor

$\Theta \quad=$ Sudut pemasangan roda pada robot

Pada saat robot melakukan pergerakan, data yang dibaca diubah untuk memperkirakan posisi relatif robot. Pergerakan robot bergantung pada pembacaan arah hadap robot dari sensor gyroscope dan pulsa dari rotary encoder. Setelah mendapatkan data jumlah pulsa dan arah hadap robot, selanjutnya adalah menghitung nilai $\mathrm{x}$ dan $\mathrm{y}$. Karena robot dilengkapi dengan 3 rotary encoder yang masing-masing dipasang pada $120^{\circ}$. Maka berlaku persamaan sebagai berikut:

$$
\begin{aligned}
& V_{x}=S_{1} * \operatorname{Cos}\left(\theta_{1}\right)+S_{2} * \operatorname{Cos}\left(\theta_{2}\right)+S_{3} * \operatorname{Cos}\left(\theta_{3}\right) \\
& V_{y}=S_{1} * \operatorname{Sin}\left(\theta_{1}\right)+S_{2} * \operatorname{Sin}\left(\theta_{2}\right)+S_{3} * \operatorname{Sin}\left(\theta_{3}\right) \\
& {\left[\begin{array}{l}
y \\
x \\
\theta
\end{array}\right]=\left[\begin{array}{ccc}
\operatorname{Cos}(\theta) & -\operatorname{Sin}(\theta) & 0 \\
\operatorname{Sin}(\theta) & \operatorname{Cos}(\theta) & 0 \\
0 & 0 & 1
\end{array}\right]\left[\begin{array}{l}
V_{y} \\
V_{x} \\
V_{\theta}
\end{array}\right]}
\end{aligned}
$$

Dimana:

$$
\begin{array}{ll}
\mathrm{S} & =\text { jarak tempuh masing-masing roda } \\
\theta_{123} & =\text { sudut pemasangan roda } \\
\mathrm{y} & =\text { posisi } \mathrm{x} \text { robot dalam koordinat kartesian } \\
\mathrm{x} & =\text { posisi y robot dalam koordinat kartesian } \\
\theta & =\text { arah hadap robot (gyroscope) }
\end{array}
$$

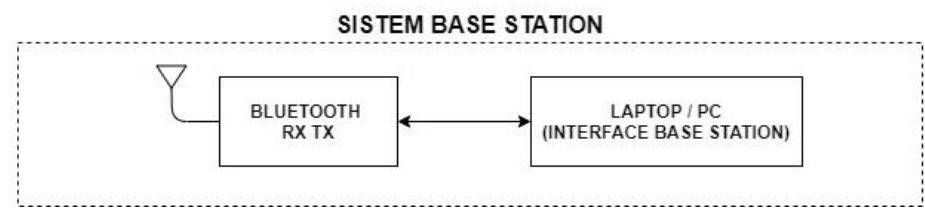

Gambar 5. Diagram blok sistem base station 
Base Station berfungsi sebagai pengontrol dan pemantau posisi robot. base station berkomunikasi dengan robot melalui media bluetooth. Data yang diterima base station merupakan data koordinat dan sudut arah hadap robot, selanjutnya data akan diproses untuk di visualisasikan ke dalam interface base station. Data hasil pengolahan base station digunakan sebagai pemantauan pergerakan robot di lapangan. Pergerakan robot ini akan menunjukkan posisi dan arahnya secara real time.

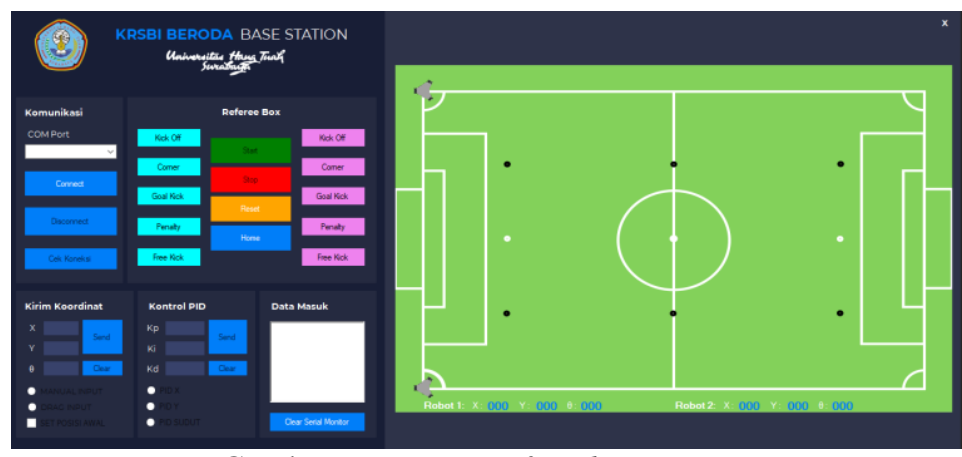

Gambar 6. User Interface base station

\section{HASIL}

Pengujian sensor rotary encoder dilakukan untuk mengetahui nilai pulsa yang dihasilkan oleh sensor rotary encoder. Pengujian ini dilakukan dengan memutar rotary encoder searah jarum jam sebanyak 1 putaran penuh, 2 putaran penuh dan 3 putaran penuh, masing-masing putaran dilakukan percobaan sebanyak lima kali.

Tabel 1. Hasil pengujian rotary encoder 1 putaran

\begin{tabular}{cccc}
\hline Percobaan & \multicolumn{3}{c}{ 1 Putaran Penuh } \\
\cline { 2 - 4 } & Pulsa Rotary 1 & Pulsa Rotary 2 & Pulsa Rotary 3 \\
\hline 1 & 271 & 270 & 268 \\
2 & 268 & 271 & 268 \\
3 & 269 & 271 & 268 \\
4 & 269 & 268 & 271 \\
5 & 268 & 269 & 268 \\
\hline Rata-rata & 269 & 269.8 & 268.6
\end{tabular}

Tabel 2. Hasil pengujian rotary encoder 2 putaran

\begin{tabular}{cccc}
\hline Percobaan & \multicolumn{3}{c}{ 2 Putaran Penuh } \\
\cline { 2 - 4 } & Pulsa Rotary 1 & Pulsa Rotary 2 & Pulsa Rotary 3 \\
\hline 1 & 538 & 535 & 538 \\
2 & 537 & 537 & 535 \\
3 & 535 & 535 & 539 \\
4 & 539 & 540 & 540 \\
5 & 539 & 540 & 535 \\
\hline Rata-rata & 537.6 & 537.4 & 537.4
\end{tabular}

Tabel 3. Hasil pengujian rotary encoder 3 putaran

\begin{tabular}{cccc}
\hline Percobaan & \multicolumn{3}{c}{ 3 Putaran Penuh } \\
\cline { 2 - 4 } & Pulsa Rotary 1 & Pulsa Rotary 2 & Pulsa Rotary 3 \\
\hline 1 & 807 & 808 & 806 \\
2 & 806 & 809 & 805 \\
3 & 810 & 808 & 807 \\
\hline
\end{tabular}




\begin{tabular}{cccc}
\hline 4 & 805 & 810 & 808 \\
5 & 806 & 807 & 810 \\
\hline Rata-rata & 806.8 & 808.4 & 807.2 \\
\hline
\end{tabular}

Pengujian sensor gyroscope dilakukan untuk mengetahui arah hadap dari sistem. Pengujian ini dilakukan dengan mengamati nilai keluaran sensor gyroscope ketika sensor diputar pada sudut tertentu, sehingga dapat dilihat perubahan nilai keluaran sensor gyroscope dan sudut sebenarnya.

Tabel 4. Hasil pengujian sensor gyroscope sudut $30^{\circ}$

\begin{tabular}{ccc}
\hline Percobaan & Sudut Target $\left(^{\circ}\right)$ & Sudut Terbaca $\left(^{\circ}\right)$ \\
\hline 1 & 30 & 30.33 \\
2 & 30 & 31.90 \\
3 & 30 & 32.48 \\
4 & 30 & 29.26 \\
5 & 30 & 30.93 \\
\hline
\end{tabular}

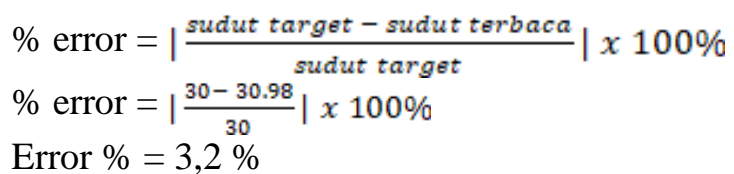

Tabel 5. Hasil pengujian sensor gyroscope sudut $45^{\circ}$

\begin{tabular}{ccc}
\hline Percobaan & Sudut Target $\left(^{\circ}\right)$ & Sudut Terbaca $\left(^{\circ}\right)$ \\
\hline 1 & 45 & 45.26 \\
2 & 45 & 45.27 \\
3 & 45 & 46.12 \\
4 & 45 & 47.66 \\
5 & 45 & 45.72 \\
\hline
\end{tabular}

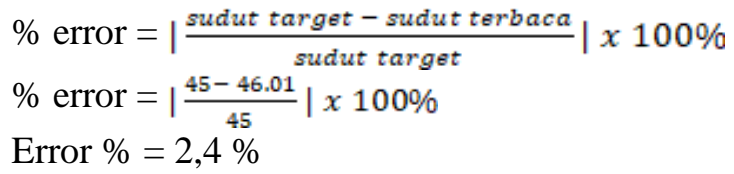

Tabel 6. Hasil pengujian sensor gyroscope sudut $60^{\circ}$

\begin{tabular}{ccc}
\hline Percobaan & Sudut Target $\left(^{\circ}\right)$ & Sudut Terbaca $\left(^{\circ}\right)$ \\
\hline 1 & 60 & 59.56 \\
2 & 60 & 62.12 \\
3 & 60 & 60.91 \\
4 & 60 & 59.20 \\
5 & 60 & 60.84 \\
\hline \multicolumn{2}{c}{} \\
\hline
\end{tabular}

\footnotetext{
$\%$ error $=\left|\frac{\text { sudut target }- \text { sudut terbaca }}{\text { sudut target }}\right| x 100 \%$

$\%$ error $=\llbracket \frac{60-60.53}{60} \mid x 100 \%$

Error $\%=0,8 \%$
}

Tabel 7. Hasil pengujian sensor gyroscope sudut $90^{\circ}$

\begin{tabular}{ccc}
\hline Percobaan & Sudut Target $\left(^{\circ}\right)$ & Sudut Terbaca $\left(^{\circ}\right)$ \\
\hline 1 & 90 & 89.53 \\
2 & 90 & 90.83 \\
\hline
\end{tabular}




\begin{tabular}{lll}
\hline 3 & 90 & 91.76 \\
4 & 90 & 89.84 \\
5 & 90 & 91.19 \\
\hline
\end{tabular}

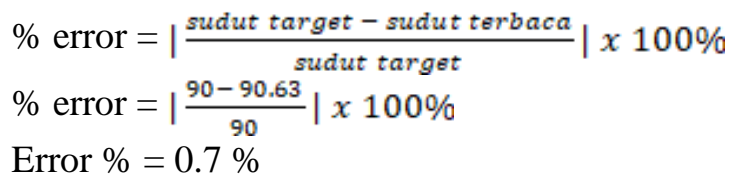

Setelah melakukan pengujian sensor gyroscope pada tahap sebelumnya, selanjutnya dilakukan analisa secara keseluruhan untuk medapatkan nilai error akhir dari pengujian sensor gyroscope. Hasil pengujian ditunjukkan pada tabel 8.

Tabel 8. Hasil pengujian sensor gyroscope keseluruhan

\begin{tabular}{ccc}
\hline Sudut Target $\left(^{\circ}\right)$ & Nilai Rata-rata $\left(^{\circ}\right)$ & Nilai Error $(\%)$ \\
\hline 30 & 30.98 & 3.2 \\
45 & 46.01 & 2.2 \\
60 & 60.53 & 0.8 \\
90 & 90.63 & 0.7 \\
\hline \multicolumn{3}{c}{ Rata-rata error $(\%)$} \\
\hline
\end{tabular}

Pengujian kontrol pergerakan robot dilakukan untuk mengetahui nilai kecepatan putar masingmasing motor untuk menggerakan robot. pengujian ini dilakukan menggunakan metode inverse kinematic nilai keluaran dari inverse kinematic berupa nilai pwm yang digunakan untuk menggerakan motor(Prayogo \& Triwiyatno, 2018). Hasil pengujian ditunjukkan pada tabel 9.

Tabel 9. Hasil pengujian inverse kinematic

\begin{tabular}{ccccccc}
\hline No & $\mathrm{Vx}$ & $\mathrm{Vy}$ & $\mathrm{V} \theta$ & $\begin{array}{c}\text { Vmotor1 } \\
(\mathrm{PWM})\end{array}$ & $\begin{array}{c}\text { Vmotor 2 } \\
(\mathrm{PWM})\end{array}$ & $\begin{array}{c}\text { Vmotor 3 } \\
(\mathrm{PWM})\end{array}$ \\
\hline 1 & 150 & 0 & 0 & $74(\mathrm{CW})$ & $150(\mathrm{CCW})$ & $75(\mathrm{CW})$ \\
2 & 0 & 150 & 0 & $129(\mathrm{CW})$ & 0 & $129(\mathrm{CCW})$ \\
3 & 150 & 150 & 0 & 204 & $150(\mathrm{CCW})$ & $54(\mathrm{CCW})$ \\
4 & 0 & 0 & 150 & 150 & 150 & 150 \\
5 & -150 & 0 & 0 & $74(\mathrm{CCW})$ & $150(\mathrm{CW})$ & $75(\mathrm{CCW})$ \\
6 & 0 & -150 & 0 & $129(\mathrm{CCW})$ & 0 & $129(\mathrm{CW})$ \\
7 & -150 & -150 & 0 & $204(\mathrm{CCW})$ & $150(\mathrm{CW})$ & $54(\mathrm{CW})$ \\
8 & 0 & 0 & -150 & $150(\mathrm{CCW})$ & $150(\mathrm{CCW})$ & $150(\mathrm{CCW})$ \\
\hline
\end{tabular}

Penggunaan kontrol PID pada tugas akhir ini berguna untuk mengoreksi sudut arah hadap robot berdasarkan pembacaan sensor gyroscope. Pengujian dilakukan untuk mengetahui kestabilan respon pada sistem kontrol robot dan waktu yang diperoleh setelah sudut arah hadap robot sesuai dengan target. Untuk mendapatkan nilai $\mathrm{Kp}, \mathrm{Ki}$, dan $\mathrm{Kd}$ terbaik pada tugas akhir ini peneliti menggunakan metode trial and error.

Setelah mendapatkan komposisi nilai $\mathrm{Kp}, \mathrm{Ki}$ dan $\mathrm{Kd}$ terbaik dengan nilai error terkecil dan waktu eksekusi tercepat, maka pada tahap selanjutnya dilakukan pengujian kontrol PID berdasarkan nilai $\mathrm{Kp}, \mathrm{Ki}$, dan $\mathrm{Kd}$ yang didapatkan. 


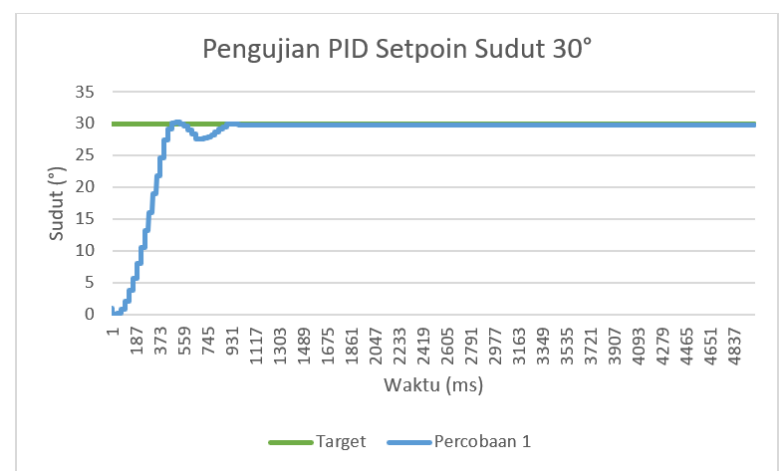

Gambar 7. Hasil pengujian PID setpoint $30^{\circ}$

Tabel 10. Hasil pengujian PID setpoint $30^{\circ}$

\begin{tabular}{|c|c|c|}
\hline Percobaan & Sudut Target & Sudut Terbaca \\
\hline 1 & 30 & 29.83 \\
\hline 2 & 30 & 30.32 \\
\hline 3 & 30 & 30.08 \\
\hline 4 & 30 & 30.49 \\
\hline 5 & 30 & 30.34 \\
\hline \multicolumn{2}{|c|}{ Rata-rata $\left(^{\circ}\right)$} & 30.21 \\
\hline
\end{tabular}
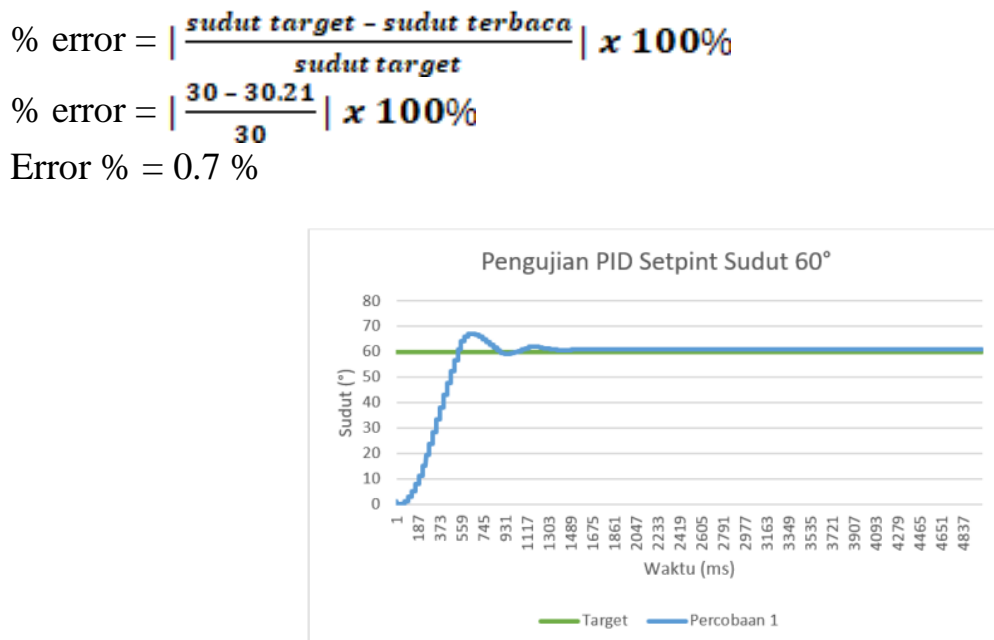

Gambar 8. Hasil pengujian PID setpoint $60^{\circ}$

Tabel 11. Hasil pengujian PID setpoint $60^{\circ}$

\begin{tabular}{ccc}
\hline Percobaan & Sudut Target & Sudut Terbaca \\
\hline 1 & 60 & 60.77 \\
2 & 60 & 60.5 \\
3 & 60 & 61.1 \\
4 & 60 & 61.26 \\
5 & 60 & 61.5 \\
\hline \multicolumn{2}{c}{} & \\
\hline
\end{tabular}

\footnotetext{
$\%$ error $=\left|\frac{\text { sudut target }- \text { sudut terbaca }}{\text { sudut target }}\right| \boldsymbol{x} \mathbf{1 0 0} \%$

$\%$ error $=\left|\frac{60-61.1}{60}\right| x 100 \%$

Error $\%=1.8 \%$
} 


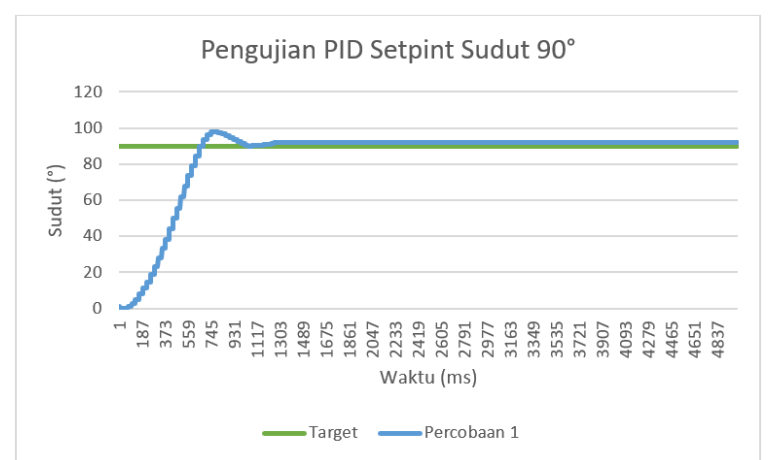

Gambar 9. Hasil pengujian PID setpoint $90^{\circ}$

Tabel 12. Hasil pengujian PID setpoint $90^{\circ}$

\begin{tabular}{ccc}
\hline Percobaan & Sudut Target & Sudut Terbaca \\
\hline 1 & 90 & 91.81 \\
2 & 90 & 92.28 \\
3 & 90 & 91.9 \\
4 & 90 & 91.93 \\
5 & 90 & 91.71 \\
\hline
\end{tabular}

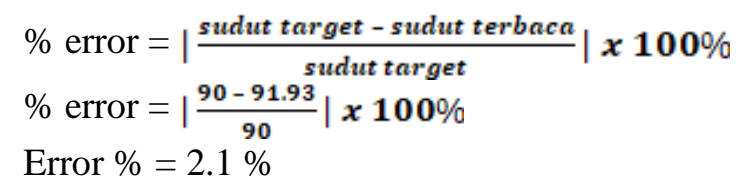

Setelah melakukan berbagai pengujian nilai PID pada tahap sebelumnya, selanjutnya dilakukan analisa secara keseluruhan untuk medapatkan nilai error akhir dari pengujian nilai PID. Hasil pengujian PID keseluruhan dapat dilihat pada tabel 13.

Tabel 13. Hasil pengujian PID keseluruhan

\begin{tabular}{ccc}
\hline Sudut Target $\left(^{\circ}\right)$ & Nilai Rata-rata $\left(^{\circ}\right)$ & Nilai Error $(\%)$ \\
\hline 30 & 30.21 & 0.7 \\
60 & 61.1 & 1.8 \\
90 & 91.93 & 2.1 \\
\hline \multicolumn{3}{c}{ Rata-rata error $(\%)$} \\
\hline
\end{tabular}

\section{PEMBAHASAN}

Pengujian odometry dilakukan untuk mengetahui apakah sistem yang dirancang dapat membaca perpindahan robot bekerja dengan baik atau tidak. Sistem ini dirancang berdasarkan jumlah pulsa yang dihasilkan oleh sensor rotary encoder yang telah terpasang. Sehingga pengujian ini dapat diketahui nilai error antara perpindahan yang telah dicapai robot secara aktual dengan nilai perpindahan robot yang dibaca oleh sensor.

Dalam pengujian ini dilakukan dalam dua tahap, tahap pertama robot bergerak menuju titik target dengan menggunakan sistem kontrol PID dan sensor gyroscope dan tahap kedua robot bergerak menuju titik target tanpa menggunakan sistem kontrol PID dan sensor gyroscope. Berikut adalah hasil pengujian perubahan posisi robot pada sumbu y dan sumbu $\mathrm{x}$ dengan menggunakan kontrol PID dan gyroscope. 
Tabel 14. Hasil pengujian pada sumbu y sejauh $200 \mathrm{~cm}$

\begin{tabular}{ccccccc}
\hline \multirow{2}{*}{ Percobaan } & \multicolumn{3}{c}{ Posisi Target } & \multicolumn{3}{c}{ Posisi Terukur } \\
\cline { 2 - 7 } & $\mathrm{X}(\mathrm{cm})$ & $\mathrm{Y}(\mathrm{cm})$ & $\theta\left(^{\circ}\right)$ & $\mathrm{X}(\mathrm{cm})$ & $\mathrm{Y}(\mathrm{cm})$ & $\theta\left(^{\circ}\right)$ \\
\hline 1 & 0 & 200 & 0 & 0 & 202 & 0 \\
2 & 0 & 200 & 0 & 0 & 202 & 0 \\
3 & 0 & 200 & 0 & 0 & 200 & 0 \\
4 & 0 & 200 & 0 & 0 & 202 & 0 \\
5 & 0 & 200 & 0 & 0 & 201 & 0 \\
6 & 0 & 200 & 0 & 0 & 199 & 0 \\
7 & 0 & 200 & 0 & -6 & 197 & 1 \\
8 & 0 & 200 & 0 & 2 & 198 & 0 \\
9 & 0 & 200 & 0 & -6 & 197 & 1 \\
10 & 0 & 200 & 0 & -1 & 199 & 2 \\
\hline Rata-rata & 66.7 & \multicolumn{5}{c}{} \\
\hline
\end{tabular}

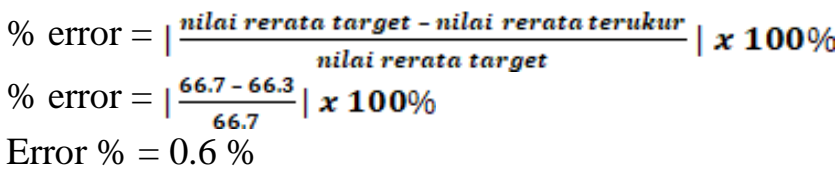

Tabel 15. Hasil pengujian pada sumbu x sejauh $200 \mathrm{~cm}$

\begin{tabular}{ccccccc}
\hline \multirow{2}{*}{ Percobaan } & \multicolumn{3}{c}{ Posisi Target } & \multicolumn{3}{c}{ Posisi Terukur } \\
\cline { 2 - 7 } 1 & $\mathrm{X}(\mathrm{cm})$ & $\mathrm{Y}(\mathrm{cm})$ & $\theta\left(^{\circ}\right)$ & $\mathrm{X}(\mathrm{cm})$ & $\mathrm{Y}(\mathrm{cm})$ & $\theta\left(^{\circ}\right)$ \\
\cline { 2 - 7 } 2 & 200 & 0 & 0 & 200 & 0 & 0 \\
3 & 200 & 0 & 0 & 198 & -1 & 0 \\
4 & 200 & 0 & 0 & 198 & 0 & 0 \\
5 & 200 & 0 & 0 & 198 & 0 & 0 \\
6 & 200 & 0 & 0 & 202 & -1 & 0 \\
7 & 200 & 0 & 0 & 198 & -1 & 0 \\
8 & 200 & 0 & 0 & 200 & 0 & 0 \\
9 & 200 & 0 & 0 & 202 & 0 & 0 \\
10 & 200 & 0 & 0 & 196 & 3 & -2 \\
Rata-rata & 200 & 0 & 0 & 197 & 1 & -2 \\
\hline
\end{tabular}

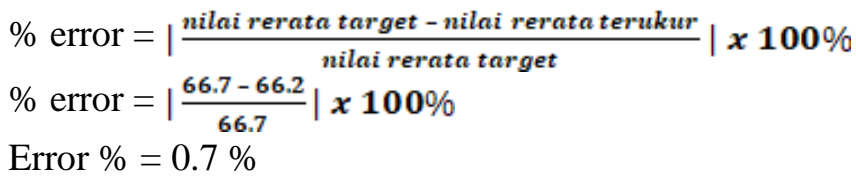

Tabel 16. Hasil pengujian pada sumbu x dan sumbu y sejauh $200 \mathrm{~cm}$

\section{Percobaan}

1

2

3

4

5

Percobaan

6200

7200

$8-200$

Posisi Target

$\mathrm{X}(\mathrm{cm}) \quad \mathrm{Y}(\mathrm{cm})$

200

200

200

200

200

Posisi Target

$X(\mathrm{~cm})$
200
200
200
200

$Y(\mathrm{~cm})$
200
200
200
200

$\mathrm{X}(\mathrm{cm})$

197

199

202

205

205

0
Posisi Terukur

$\begin{array}{cc}\text { Y }(\mathrm{cm}) & \theta\left(^{\circ}\right) \\ 201 & 1 \\ 208 & 1 \\ 200 & 0 \\ 202 & 0 \\ 203 & 1\end{array}$

Posisi Terukur

$\begin{array}{cccc}\theta\left(^{\circ}\right) & \mathrm{X}(\mathrm{cm}) & \mathrm{Y}(\mathrm{cm}) & \theta\left(^{\circ}\right) \\ 0 & 205 & 202 & 0 \\ 0 & 198 & 202 & 2 \\ 0 & 206 & 199 & 1 \\ 0 & 204 & 199 & 1\end{array}$


48 Jurnal Borneo Informatika \& Teknik Komputer, Vol. 1, No. 1, 2021. HIm 38-51

\begin{tabular}{ccccccc}
\hline 10 & 200 & 200 & 0 & 194 & 199 & 0 \\
\hline Rata-rata & 200 & 200 & 0 & 201.5 & 201.5 & 0.7 \\
& & 133.3 & & & 134.6 & \\
\hline
\end{tabular}

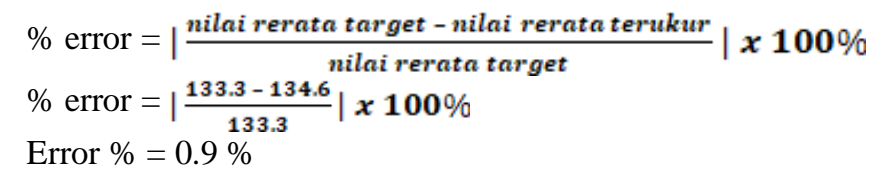

Berikut adalah hasil pengujian perubahan posisi robot pada sumbu y dan sumbu $\mathrm{x}$ tanpa menggunakan kontrol PID dan gyroscope.

Tabel 17. Hasil pengujian pada sumbu y sejauh $200 \mathrm{~cm}$

\begin{tabular}{ccccccc}
\hline Percobaan & \multicolumn{3}{c}{ Posisi Target } & \multicolumn{3}{c}{ Posisi Terukur } \\
\cline { 2 - 7 } & $\mathrm{X}(\mathrm{cm})$ & $\mathrm{Y}(\mathrm{cm})$ & $\theta\left(^{\circ}\right)$ & $\mathrm{X}(\mathrm{cm})$ & $\mathrm{Y}(\mathrm{cm})$ & $\theta\left(^{\circ}\right)$ \\
\hline 1 & 0 & 200 & 0 & 0 & 207 & -1 \\
2 & 0 & 200 & 0 & -8 & 204 & -2 \\
3 & 0 & 200 & 0 & -2 & 205 & -1 \\
4 & 0 & 200 & 0 & 6 & 205 & -4 \\
5 & 0 & 200 & 0 & 0 & 206 & 0 \\
6 & 0 & 200 & 0 & 2 & 204 & 0 \\
7 & 0 & 200 & 0 & -4 & 205 & 0 \\
8 & 0 & 200 & 0 & 2 & 205 & -6 \\
9 & 0 & 200 & 0 & -6 & 205 & 1 \\
10 & 0 & 200 & 0 & -6 & 204 & 1 \\
rata-rata & 0 & 200 & 0 & -1.6 & 205 & -1.2 \\
& & 66.7 & & & 67.4 & \\
\hline
\end{tabular}

\footnotetext{
$\%$ error $=\left|\frac{\text { nilai rerata target }- \text { nilai rerata terukur }}{\text { nilai rerata target }}\right| \boldsymbol{x} 100 \%$

$\%$ error $=\left|\frac{66.7-67.4}{66.7}\right| x 100 \%$
}

Error $\%=1 \%$

Tabel 18. Hasil pengujian pada sumbu x sejauh $200 \mathrm{~cm}$

\begin{tabular}{ccccccc}
\hline Percobaan & \multicolumn{3}{c}{ Posisi Target } & \multicolumn{3}{c}{ Posisi Robot } \\
& $\mathrm{X}(\mathrm{cm})$ & $\mathrm{Y}(\mathrm{cm})$ & $\theta\left(^{\circ}\right)$ & $\mathrm{X}(\mathrm{cm})$ & $\mathrm{Y}(\mathrm{cm})$ & $\theta\left(^{\circ}\right)$ \\
\hline 1 & 200 & 0 & 0 & 212 & -12 & 52 \\
2 & 200 & 0 & 0 & 228 & -14 & 53 \\
3 & 200 & 0 & 0 & 206 & -10 & 52 \\
4 & 200 & 0 & 0 & 204 & -12 & 51 \\
5 & 200 & 0 & 0 & 204 & -14 & 50 \\
6 & 200 & 0 & 0 & 218 & -13 & 52 \\
7 & 200 & 0 & 0 & 194 & -11 & 50 \\
8 & 200 & 0 & 0 & 198 & -10 & 51 \\
9 & 200 & 0 & 0 & 190 & -13 & 52 \\
10 & 200 & 0 & 0 & 204 & -10 & 52 \\
\hline rata-rata & 200 & 0 & 0 & 205.8 & -11.9 & 51.5 \\
& & 66.7 & & & 81.8 & \\
\hline
\end{tabular}

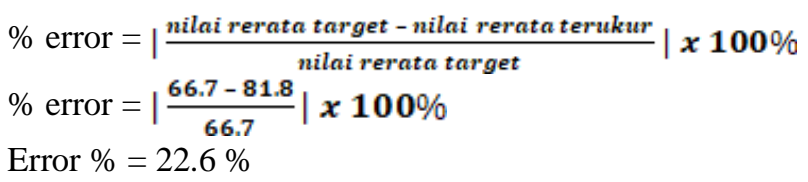


Tabel 19. Hasil pengujian pada sumbu x dan sumbu y sejauh $100 \mathrm{~cm}$

\begin{tabular}{ccccccc}
\hline Percobaan & \multicolumn{3}{c}{ Posisi Target } & \multicolumn{3}{c}{ Posisi Robot } \\
\cline { 2 - 7 } & $\mathrm{X}(\mathrm{cm})$ & $\mathrm{Y}(\mathrm{cm})$ & $\theta\left({ }^{\circ}\right)$ & $\mathrm{X}(\mathrm{cm})$ & $\mathrm{Y}(\mathrm{cm})$ & $\theta\left({ }^{\circ}\right)$ \\
\hline 1 & 100 & 100 & 0 & 88 & 105 & 0 \\
2 & 100 & 100 & 0 & 90 & 105 & -3 \\
3 & 100 & 100 & 0 & 96 & 105 & -2 \\
4 & 100 & 100 & 0 & 98 & 104 & -2 \\
5 & 100 & 100 & 0 & 96 & 104 & -3 \\
6 & 100 & 100 & 0 & 96 & 105 & -6 \\
7 & 100 & 100 & 0 & 94 & 106 & -33 \\
8 & 100 & 100 & 0 & 96 & 105 & -2 \\
9 & 100 & 100 & 0 & 90 & 105 & -4 \\
10 & 100 & 100 & 0 & 94 & 116 & 14 \\
\hline rata-rata & 100 & 100 & 0 & 93.8 & 106 & -4.1 \\
& & 66.7 & & & 65.2 & \\
\hline
\end{tabular}

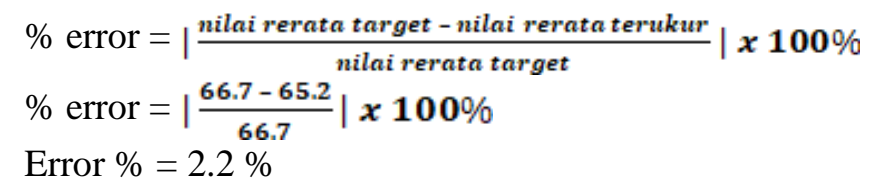

Pengujian base station dilakukan untuk mengetahui apakah sistem base station dapat mengirim data ke robot dan dapat menerima data dari robot. Pada tahap ini juga dilakukan pengujian terhadap visualisasi robot yang terdapat pada aplikasi base station. Sehingga pengujian ini dapat diketahui perpindahan yang telah dicapai robot secara real time. Base station menggunakan media bluetooth sebagai media komunikasinya.

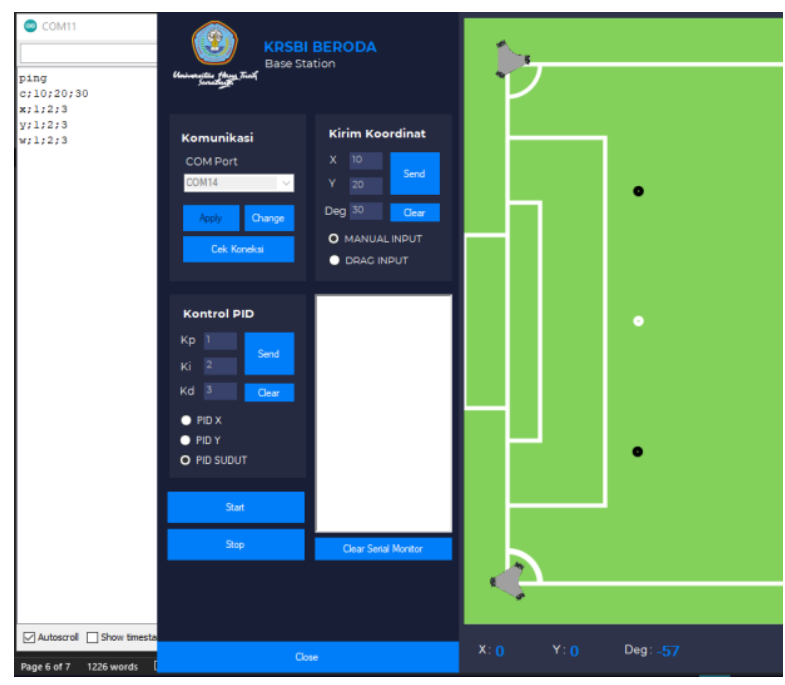

Gambar 10. Hasil pengiriman data dari base station ke robot 


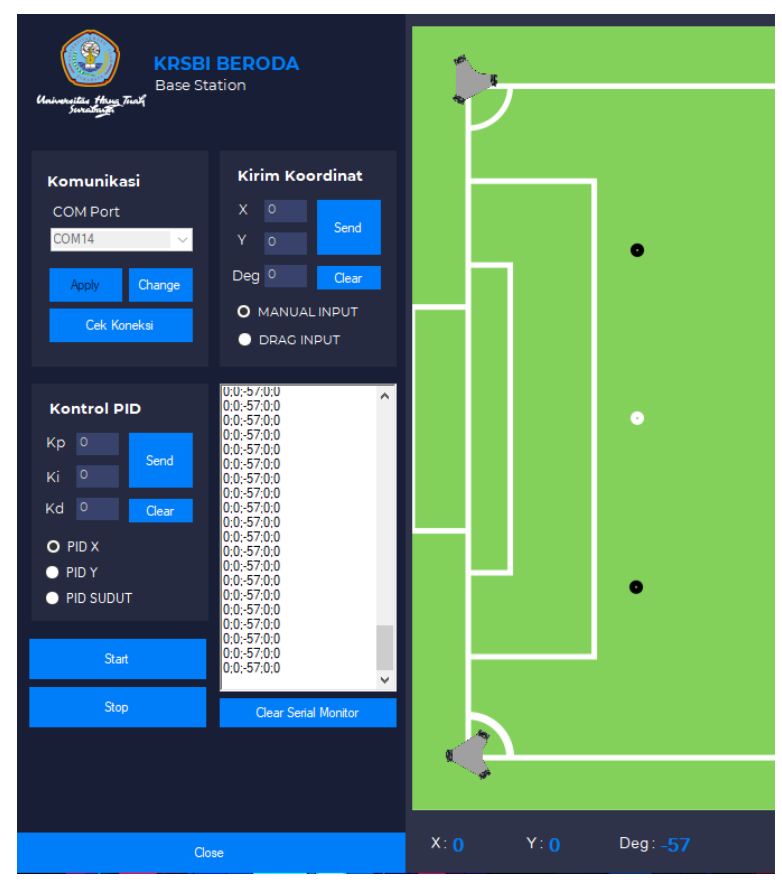

Gambar 11. Hasil penerimaan data dari robot

\section{KESIMPULAN}

Pada pengujian kontrol PID untuk mengontrol arah hadap robot, penggunaan metode trial and error dalam menentukan nilai $\mathrm{Kp}, \mathrm{Ki}$ dan $\mathrm{Kd}$ didapatkan hasil respon sistem dengan waktu eksekusi yang cepat dan nilai error yang kecil. Pada pengujian perubahan posisi robot sejauh $200 \mathrm{~cm}$ pada sumbu y, dengan menggunakan sistem kontrol PID dan sensor gyroscope didapatkan hasil error sebesar $0.6 \%$ sedangkan pengujian tanpa menggunakan sistem kontrol PID dan gyroscope didapatkan hasil error sebesar $1 \%$. Pada pengujian perubahan posisi robot sejauh $200 \mathrm{~cm}$ pada sumbu $\mathrm{x}$, dengan menggunakan sistem kontrol PID dan sensor gyroscope, didapatkan hasil error sebesar $0.7 \%$, sedangkan pengujian tanpa menggunakan sistem kontrol PID dan gyroscope didapatkan hasil error sebesar $22.6 \%$.

Pada pengujian perubahan posisi robot sejauh $200 \mathrm{~cm}$ pada sumbu x dan $200 \mathrm{~cm}$ pada sumbu $\mathrm{y}$, dengan menggunakan sistem kontrol PID dan sensor gyroscope didapatkan hasil error sebesar $0.9 \%$, sedangkan pengujian perubahan posisi robot sejauh $100 \mathrm{~cm}$ pada sumbu $\mathrm{x}$ dan $100 \mathrm{~cm}$ pada sumbu y, tanpa menggunakan sistem kontrol PID dan gyroscope didapatkan hasil error sebesar $2.2 \%$. Pada pengujian perubahan posisi robot sejauh $200 \mathrm{~cm}$ pada sumbu $\mathrm{x}$ dan $200 \mathrm{~cm}$ pada sumbu $\mathrm{y}$, dengan menggunakan sistem kontrol PID dan sensor gyroscope didapatkan hasil error sebesar $0.9 \%$, sedangkan pengujian perubahan posisi robot sejauh $100 \mathrm{~cm}$ pada sumbu $\mathrm{x}$ dan $100 \mathrm{~cm}$ pada sumbu y, tanpa menggunakan sistem kontrol PID dan gyroscope didapatkan hasil error sebesar $2.2 \%$.

Dengan pembacaan sistem odometry yang lebih baik berdampak pada pemosisian robot yang lebih akurat. Hal ini terlihat dari perbandingan nilai error metode odometry menggunakan kontrol PID dan sensor gyroscope dengan metode odometry tanpa menggunakan kontrol PID dan sensor gyroscope. Berdasarkan hasil tersebut metode odometry dengan menggabungkan sistem kontrol PID dan sensor gyroscope dapat memperbaiki error robot dan meningkatkan performa dalam melakukan pemosisian. 


\section{REFERENSI}

Abseno, A. P. (2019). Penerapan Kinematika Untuk Lokalisasi Pada Robot Sepak Bola Beroda. 73.

Basori, S., Sulistiyanto, N., \& Rif'an, M. (2014). Implementasi Odometry Pada Robot Otomatis Kontes Robot Abu Indonesia. Slamet Basori.1, Nanang Sulistiyanto, Ir., MT.2, Mochammad Rif'an, ST., MT.2, 5.

Firman, B. (2016). Implementasi Sensor IMU MPU6050 Berbasis Serial I2C Pada Self-Balancing Robot Vol . 9 No . 1 Agustus 2016 ISSN : 1979-8415. Juenal Teknologi Technoscientia, 9(1), 18-24.

Kemahasiswaan Direktorat Jenderal Pembelajaran dan Kemahasiswaan Kementerian Riset, D., \& dan Pendidikan Tinggi, T. (2018). Buku Panduan Kontes Robot Sepakbola Indonesia Beroda (KRSBI Beroda) 2019.

Khumaidi, A., Nasikhin, K., Priyonggo, P., Santoso, M., Bagus, D., Sahputra, A. W., Kapal, T. K., Otomasi, P. T., Kapal, T. P., Perkapalan, P., \& Surabaya, N. (2021). Pemetaan Posisi Robot Soccer Menggunakan Gyrodometry. 19(3).

Marisa, S., Wahyuni, T., \& Kunci, K. (2020). Rancang Bangun Prototipe Sistem Saluran Air Berbasis Sistem Tutup Buka Otomatis Menggunakan Sistem Mikroprosesor dan Sensor Ultrasonic. 26-27.

Nasir, M. (2020). Penerapan Gyrodometry pada Three Omni Wheels untuk Robot Sepak Bola Beroda.

Prayogo, R. C., \& Triwiyatno, A. (2018). Perancangan Robot Berkaki 4 ( Quadruped ) Dengan Stabilization Algorithm Pada Uneven Floor Menggunakan 6-Dof Imu Berbasis Invers Kinematic. Transient, 7(2), 543-551.

Rachmawan, A. (2017). Penentuan Posisi Robot Sepak Bola Beroda Menggunakan Rotary Encoder dan Kamera. Undergraduate Thesis, Jurusan Teknik Elektro, Fakultas Teknologi Industri, Institut Teknologi Sepuluh Nopember, Surabaya.

Rifandi, S. (2020). Navigasi Mobile Robot Untuk Mencapai Docking Station Dalam Proses Autodocking. Jurnal Elektronika, Listrik, Telekomunikasi, Komputer, Informatika, Sistem Kontrol (J-Eltrik), 2(1). https://doi.org/10.30649/j-eltrik.v2i1.54 